\title{
A Geographical List in Hebrew \\ Previously Ascribed \\ to Abraham Bar Hiyyar
}

\author{
BERNARD R. GOLDSTEIN \\ Dietrich School of Arts and Sciences \\ University of Pittsburgh \\ Pittsburgh, PA I5260, USA \\ brg@pitt.edu
}

\begin{abstract}
A geographical list in Hebrew was published in I85I as an appendix to a treatise on the calendar by Abraham Bar Hiyya (d. ca. I I36). It is argued here that this list has nothing to with Bar Hiyya; rather, it was copied from the Tables of Barcelona (second half of the fourteenth century), and derives in part from the geographical list in the zij of Ibn al-Kammād (early twelfth century).
\end{abstract}

Keywords: Coordinates of cities, Tables of Barcelona, Ibn al-Kammād, Meridian of Water, Soria (Castile)

Abraham Bar Hiyya of Barcelona (d. ca. I I36) compiled the first set of astronomical tables in Hebrew, and it was largely based on the zij of al-Battānī (d. 929). Although, in many zijes, including that of al-Battān̄̄, there is a list of cities with their geographical coordinates, ${ }^{2}$ no such list is found in the published version of Bar Hiyya's set of tables. ${ }^{3}$ However, in Filipowski's edition of Abraham

I. I am grateful to Ofer Elior who sent me electronic copies of pages in several Hebrew manuscripts, to José Chabás for his comments on a draft of this paper, to Ilana Wartenberg for comments on Bar Hiyya's treatise on the calendar, and to two anonymous referees for information about geographical lists ascribed to Abraham Ibn Ezra and Abraham Bar Hiyya. Julio Samsó kindly provided me with information on Arabic dialects in Andalusia.

2. Nallino I899-I907, 2:33-54.

3. Millás I959. For Bar Hiyya’s tables Millás consulted 4 manuscripts: see p. I Io. See also n. I4, below.

Goldstein, Bernard R. (2018-2019). «A Geographical List in Hebrew Previously Ascribed to Abraham Bar Hiyya». Suhayl I6-I 7, pp. I I3-I I 9. ISSN: I 576-9372. DOI: I0. I344/SUHAYL20 I9. I6-I 7.3. 
Bar Hiyya's treatise on the calendar, Sefer ha- 'ibbur, published in I85I, there is a list of cities with their coordinates appended to the text. ${ }^{4}$ Indeed, it has been accepted that the list published by Filipowski was compiled by Abraham Bar Hiyya. ${ }^{5}$ Nevertheless, on the basis of the evidence presented here, we conclude that, despite Filipowski, the list of cities with their coordinates that he published has nothing to do with Bar Hiyya. ${ }^{6}$ This geographical list is of particular interest because it is based on the "meridian of water" which was approximately $17 ; 30^{\circ}$ to the west of the standard meridian based on the Fortunate Islands (= the Canary Islands). Thus, the longitude of Toledo is given here as $28 ; \mathrm{I}^{\circ}$, rather than $\mathrm{II}^{\circ}$ which is its longitude from the standard meridian. ${ }^{7}$ In 1994 Comes called attention to the importance of the meridian of water in geographical lists, and included Bar Hiyya among those who used it. ${ }^{8}$

On the title page of his edition, Filipowski indicated that he depended on a manuscript in Oxford and an unspecified manuscript in Paris. I have checked the one manuscript of Sefer ha- 'ibbur in Oxford (Bodleian Library, MS Opp. I83 = Neubauer No. 20I6), the three manuscripts in Paris (Bibliothèque nationale de France, MSS Heb. 805, I047, and I06I, as well as copies in Munich, Bayerische Staatsbibliothek, MS Heb. 36, and Vatican, Biblioteca Apostolica, MS Heb. 386. The Oxford copy, dated 7 Nisan 5236 A.M. (= I April I476), is the only one to which a geographical list is appended. The singular occurrence of this table in manuscripts of Bar Hiyya's treatise is the first indication that Filipowski may have incorrectly assigned this list to Bar Hiyya.

4. Filipowski I85 I, p. I 20.

5. As far as I can determine, Millás (I949, p. 249) was the only scholar to cast doubt on Bar Hiyya's authorship of this list.

6. Shlomo Sela kindly informed me about a list of cities with their coordinates (in degrees only), compiled in the twelfth century by Abraham Ibn Ezra and preserved in the third version of his treatise on the astrolabe, Keli ha-nehošet: see, e.g., Paris, Bibliothèque nationale de France, MS Heb. I03 I, I 54a, and MS Heb. I054, 9b. Ibn Ezra's list differs from the list published by Filipowski. Cf. Sela 2003, p. 30.

7. For other geographical lists in Hebrew, see Goldstein 20 I 8; Goldstein and Chabás 2017, pp. 366-368; Goldstein 200I, p. 263; and Cohn I9I8, pp. 3I-33. The relative paucity of geographical lists in Hebrew stands in contrast to the vast number of such lists in Arabic: see Kennedy and Kennedy I987.

8. Comes I 994, p. 47. Comes cited Laguarda ( I988, pp. 45-47, 66) who, in turn, depended on Filipowski's edition of I85I. 
Filipowski's list agrees with that on f. 42 a of the Oxford manuscript: the cities are listed in the same order, and their coordinates are the same, but for a few mistakes in the transcription. However, Filipowski added an entry for Soria (Castile), with coordinates, in a row above the entry for Santarin: Filipowski's source is probably the geographical list in Abraham Zacut's Almanach Perpetuum, ${ }^{9}$ for Soria does not appear in the geographical list in the Oxford manuscript, although it is mentioned in the heading of a calendrical table on $\mathrm{f}$. 43a, "Table for finding the molad (conjunction) according to the mean motion for Soria". ${ }^{\text {Io }}$

The key finding is that the geographical list in the Oxford manuscript is identical, but for a few variants, with the corresponding list in Hebrew manuscripts of the Tables of Barcelona (The Tables of King Peter IV of Aragon: second half of the fourteenth century): Vatican, Bibilioteca Apostolica, MS Heb. 356, 44b, and MS Heb. 379, I74b; and Parma, Biblioteca Palatina, MS 29I5 (= de Rossi I65), 9b. The list in the Oxford manuscript and in the Hebrew copies of the Tables of Barcelona is headed "Table for the longitudes of cities [counted] from the beginning of the inhabited world (ha-yiššub) [in the West] ${ }^{11}$ and their latitudes from the equator": see Appendix. The Oxford list has 22 entries (or 23, if Perpignan is included), ${ }^{\mathrm{I} 2}$ beginning with Santarin (= Santarem, Portugal) and ending with Mecca; the list in Vatican, MS 379, has 22 entries, beginning with Santarin and ending with Mecca. The list in Vatican, MS 356, has 23 entries, beginning with Santarin and ending with Burgos after the entry for Mecca. The 22 cities in common in these two Vatican manuscripts are in the same order and have the same coordinates (with minor variants) as the 22 cities

9. See Zacut I496, I68v, where the coordinates of Soria are $28 ; \mathrm{I} 3^{\circ}$ (long.); $4 \mathrm{I} ; 3^{\circ}$ (lat.), exactly as in Filipowski I85 I, p. I20. For the same data in the Hebrew version of Zacut's Almanach Perpetuum, see Cohn I9I 8, p. 33 .

I0. This table is transcribed in Filipowski I85 I, p. I I9. Based on the occurrence of Soria in the heading for this table, Filipowski (p. vii) assumed that Soria was Bar Hiyya's place of birth or his place of residence. It seems, however, that this table has nothing to do with Bar Hiyya, and that it is one of several tables appended to Bar Hiyya's text in the Oxford manuscript.

I I. Omitted in the Oxford manuscript.

I 2. Filiowski's list has a single entry for Monpesler [= Montpellier] and Perpignan, whereas in the Oxford manuscript the entry is for Montpellier, with Perpignan added in small letters below it in the same cell enclosed by the grid lines. In the other copies of this list in Hebrew (Vat. 356, Vat. 379, and Parma 29I5) Montpellier is included but Perpignan is not, and this is also the case for the version in Catalan. 
in the Oxford manuscript. The entries at the beginning of the list in the Parma manuscript are illegible due to water damage; the last entry is Tarascon (in Provence) which comes after Mecca, where Tarascon is written in a different hand. In Millás's edition of the Tables of Barcelona, the geographical list of 29 cities with their coordinates is based on the Catalan version, of which I 8 entries agree with those in the Latin version of Ibn al-Kammād's al-Zīj al-muqtabis: see Madrid, Biblioteca Nacional de España, MS I0023, 54V. ${ }^{13}$ All 22 entries in the Hebrew list also appear in the Catalan version of the Tables of Barcelona, with minor variants.

It has recently come to my attention that in one copy of Bar Hiyya's set of astronomical tables, there is a list of 26 cities with their coordinates: Chicago, Newberry College, MS Heb. 2, 4a. ${ }^{\mathrm{I}}$ It is not clear if this list goes back to Bar Hiyya but, in any event, it is different from the list in the Oxford manuscript. The first entry in this list is for Paris with coordinates 20;0 (long.), $48^{\circ}$ (lat.), and the second entry is for Marseille (מרשלייה) ${ }^{15}$ with coordinares $28^{\circ}$ (long.), $44^{\circ}$ (lat.). Neither of these two cities is listed in the Oxford manuscript. Toledo's coordinates in the Chicago manuscript are $28 ; 30^{\circ}$ (long.) and 39;54 (lat.), whereas in the Oxford manuscript they are $28 ; 15^{\circ}$ and $39 ; 52^{\circ}$, respectively. It is surely noteworthy that Barcelona, where Bar Hiyya was active, is not included in the list in the Chicago manuscript: this omission casts doubt on his authorship of that list.

It seems then that the copyist of the Oxford manuscript, probably in Soria or Perpignan, appended the geographical list in the Tables of Barcelona to Abraham Bar Hiyya's treatise on the calendar, and this list was not compiled by Bar Hiyya.

13. Millás 1962, p. I38, and Chabás 1996, p. 515; see also Chabás and Goldstein I994, pp. $35-36$.

I4. This manuscript was not consulted by Millás: see n. 3, above. This list is also different from Ibn Ezra's list: see n. 6, above.

I5. For the Hebrew name of Marseille, see Gross I897, p. 366. 
Appendix:

Table of the Longitudes of Cities [Counted] from the Beginning of the Inhabited World [in the West] and their Latitudes from the Equator: Oxford, Bodleian Library, MS Opp. I $83,42 \mathrm{a}$

\begin{tabular}{|c|c|c|c|}
\hline NAmes of the Cities & Climate & LONGITUDE & LATITUDE \\
\hline Santarin $[=$ Santarem $]$ & 5 & $23 ; 40^{\circ}$ & $40 ; 15^{\circ}$ \\
\hline Nubia $^{a}$ & 4 & $24 ; 10$ & $35 ; \mathrm{I} 5$ \\
\hline Fas $[=\mathrm{Fez}]$ & 4 & $25 ; 0$ & $33 ; 0$ \\
\hline Sebta $[=$ Ceuta $]$ & 4 & $25 ; 40$ & $35 ; 20$ \\
\hline Sevilla & 5 & $25 ; 40$ & $37 ; 15$ \\
\hline Malaqa [= Malaga] & 5 & $26 ; 22^{\mathrm{b}}$ & $37 ; 0$ \\
\hline Córdoba & 5 & $27 ; 0$ & $38 ; 30$ \\
\hline Granada & 5 & $27 ; 30$ & $37 ; 30$ \\
\hline Almería & 5 & $28 ; 0$ & $36 ; 30$ \\
\hline Toledo & 5 & $28 ; 15^{\mathrm{c}}$ & $39 ; 52$ \\
\hline Murcia & 5 & $29 ; 30$ & $37 ; 30$ \\
\hline Valencia & 4 & $30 ; 20$ & $36 ; 25$ \\
\hline Mallorca & 4 & $37 ; 0$ & $39 ; 0$ \\
\hline Barcelona & 5 & $33 ; 0$ & 4I;IO \\
\hline Sicily & 4 & $65 ; 20$ & $37 ; 30$ \\
\hline Alexandria & 4 & $63 ; 0$ & $3 \mathrm{I} ; 0$ \\
\hline Egypt & 3 & $64 ; 50$ & $29 ; 55$ \\
\hline Gerona & 4 & $30 ; 0$ & $4 \mathrm{I} ; 30$ \\
\hline $\begin{array}{l}\text { Monpesler [= Montpellier] } \\
\text { Perpignan }^{\mathrm{d}}\end{array}$ & $\begin{array}{l}4 \\
4\end{array}$ & $\begin{array}{l}32 ; 10 \\
32 ; 30\end{array}$ & $\begin{array}{l}43 ; 0 \\
-\end{array}$ \\
\hline Toulouse & 5 & $50 ; 0$ & $42 ; 45$ \\
\hline Jerusalem & 4 & $69 ; 30$ & $32 ; 0$ \\
\hline Mecca & 2 & $79 ;$ о & $2 \mathrm{I} ; 40$ \\
\hline
\end{tabular}

a. With Vat. MS 379, read: Țanya [= Ar. Țanja; Eng. Tangier]. ${ }^{16}$ Vat. MS 356: Nunya. In the edition of the Tables of Barcelona (Millás I962, p. I38), and in Ibn al-

I6. Although it is unusual, there are other examples of the shift from $/ \mathrm{j} /$ to $/ \mathrm{y} /$ in Andalusian Arabic: see Corriente I977, p. 52. See also Goldstein I967, p. 280 (P I 2b:6, 8, etc.), where Ibn Ezra 
Kammād's zij (Madrid, MS I0023, 54v), the corresponding entry with the same coordinates is for Tangier.

b. Vat. MS 379: 26;22; Vat. MS 356: 26;0.

c. Vat. MS 379: 28; I5; Vat. MS 356: 28;3 I.

d. Perpignan occurs in the Oxford MS, but not in Vat. MS 356, Vat. MS 379, or Parma MS 29I5.

\section{REFERENCES}

ChabÁs, J. I996. “Astronomía andalusí en Cataluña: Las tablas de Barcelona”, in J. Casulleras and J. Samsó (eds.), From Baghdad to Barcelona: Studies in the Islamic exact sciences in honour of Prof. Juan Vernet (Barcelona), pp. 477-525.

Chabás, J. and B. R. Goldstein. I994. "Andalusian Astronomy: al-Zīj al-muqtabis of Ibn al-Kammād", Archive for History of Exact Sciences 48: I-4I .

ChabÁs, J. and B. R. Goldstein. 2003. The Alfonsine Tables of Toledo (Dordrecht and Boston).

Cohn, B. I9I8. Der Almanach perpetuum des Abraham Zacuto (Strassburg).

Comes, M. I994. "The 'Meridian of Water' in the Tables of Geographical Coordinates of al-Andalus and North Africa", Journal for the History of Arabic Astronomy I0:4 I5I. Reprinted in M. Rius Piniés and S. Gómez Muns (eds.), 2013, Homenaje a Mercè Comes: Coordenadas del Cielo y de la Tierra (Barcelona), pp. 377-388.

Corriente, F. I977. A Grammatical Sketch of the Spanish Arabic Dialect Bundle (Madrid).

Filipowski H. (ed.). I85I . Abraham Bar Hiyya: Sefer ha-'ibbur (London).

Goldstein, B. R. I967. Ibn al-Muthannā's Commentary on the Astronomical Tables of al-Khwārizmī: Two Hebrew Versions (New Haven and London).

Goldstein, B. R. 200I. "The astronomical tables of Judah ben Verga", Suhayl 2:227289.

Goldstein, B. R. 20I 8. "Notes on Hebrew Lists of Geographical Coordinates of Cities", Aleph I 8:265-27I.

Goldstein, B. R. and J. Chabás 20i7. "The Astronomical Tables of Isaac ben Joseph Israeli of Toledo", Aleph I 7:357-370.

Gross, H. I897. Gallia Judaica (Paris).

transliterated Arabic jaib (sine) into Hebrew as yaiba (ייבא); and Chabás and Goldstein 2003, p. 24 (ch. 4:I I), where the Arabic month Rajab is transliterated into medieval Castilian as raiab. 
Kennedy, E. S. and M. H. Kennedy. I987. Geographical Coordinates of Localities from Islamic Sources (Frankfurt am Main).

Laguarda Trias, R. A. I988. Fundamentación histórica del descubrimiento de América (Montevideo).

Millás, J. M. I949. Estudios sobre historia de la ciencia española (Barcelona).

Millás, J. M. (ed.). 1959. La obra Séfer Hešbon mahlekot ha-kokabim de R Abraham Bar Hiyya ha-Bargeloni (Barcelona).

Millás, J. M. (ed.). I962. Las tablas astronómicas del Rey Don Pedro el Ceremonioso (Madrid-Barcelona).

Nallino, C.A. (ed. and tr.). I899-1907. Al-Battān̄̄ sive Albatenii Opus astronomicum. 3 vols. (Milan).

SELA, S. 2003. Abraham Ibn Ezra and the Rise of Medieval Hebrew Science (Leiden and Boston).

Zacut, A. I496. Almanach Perpetuum (Leiria). 
